\title{
DIE GELYKENIS VAN DIE VERLORE SEUN: EERSTE-EEUSE EKONOMIE EN DIE HOORDERS VAN JESUS
}

WJ Schoeman ${ }^{1}$ en Ernest van Eck Universiteit van Pretoria

\begin{abstract}
Jesus preached the kingdom of God, with the principle of general reciprocity as a cardinal aspect. For Jesus, this kingdom was an alternative social world to the oppressive and exploitative social system of the Greco-Roman world. This article seeks to analyse the parable of the Lost Son (Luke 15:11-32), focusing on Luke 15:11-13, against the socio-economic background of first century Palestine. Special attention is given to the youngest son's decision to leave the house and his possible motive for doing so. The view is that texts are the products of the specific social systems in which they originated, and therefore the social scientific approach is used to analyse this text. The conclusion reached is that the political and tax systems of the Greco-Roman world were extremely exploitative, while the kingdom of God, as an alternative social order, advocated the principle of general reciprocity and the sharing of resources.
\end{abstract}

Key words: Parables; Parable of the Lost Son; Luke 15; Sustainability; General reciprocity; Ancient economy

\section{Opsomming}

Jesus het die koninkryk van God verkondig, met die beginsel van algemene wederkerigheid as 'n kardinale aspek daarvan. Vir Jesus was dié koninkryk 'n alternatiewe sosiale wêreld teenoor en die onderdrukkende en uitbuitende sosiale stelsel van die Grieks-Romeinse wêreld. Hierdie artikel poog om die gelykenis van die Verlore Seun (Lukas 15:11-32), met as fokus Lukas 15:11-13, te analiseer teen die sosio-ekonomiese agtergrond van Palestina in die eerste eeu. Spesiale aandag word gegee aan die jongste seun se besluit om die huis te verlaat en moontlike motief daaragter. Daar word van die standpunt uitgegaan dat tekste die produkte is van die spesifieke sosiale stelsels waarin hulle ontstaan het, en daarom word die sosiaal-wetenskaplike benadering gebruik om dié teks te analiseer. Die konklusie waartoe gekom word, is dat die politieke- en belastingstelsel van die Grieks-Romeinse wêreld uiters uitbuitend was, terwyl die koninkryk van God, as alternatiewe sosiale orde, die beginsel van algemene wederkerigheid en die deel van hulpbronne voorgestaan het.

Hierdie artikel is 'n verwerking van sekere aspekte van W.J. Schoeman se PhD-tesis: "Die gelykenis van die Verlore Seun: Die eerste-eeuse ekonomie en die hoorders van Jesus", in die Departement Nuwe Testament en Verwante Literatuur, Fakulteit Teologie en Religie, aan die Universiteit van Pretoria, onder die studieleiding van Prof. Dr. Ernest van Eck. 
Sleutelwoorde: Gelykenisse; Gelykenis van die Verlore Seun; Lukas 15; Volhoubaarheid; Algemene wederkerigheid; Antieke ekonomie

\section{Inleiding}

Tot op hede is daar weinig tot geen studies gedoen wat die gelykenis van die Verlore Seun in Lukas 15:11-32 in terme van die 27-30 nC sosio-ekonomiese agtergrond daarvan bestudeer het nie. Hierdie artikel poog om sekere aspekte van die navorsingsleemte aan te spreek deur die gelykenis van die Verlore Seun te analiseer teen die agtergrond van die eerste-eeu waartydens Jesus ${ }^{2}$ sy gelykenisse vertel het, Die fokus is dus nie daarop om die gelykenis te lees in terme van die sosiohistoriese konteks van die Lukas-evangelie nie, maar in terme van die sosio-ekonomiese konteks van die eerste-eeuse Palestina waartydens die historiese Jesus (27-30 nC) sy gelykenisse vertel het. Hedrick (2004: xvi; beklemtoning in die oorspronklike) verduidelik hierdie verskil betreffende fokus soos volg:

If one is interested in the evangelist's understanding of the parable, reading begins with the literary context, but if one is interested in the parable in the context of Jesus' public career some forty years or so earlier than the gospels, reading begins with the parable and ignores the literary setting. Those who begin with the literary setting proceed on the assumption that the literary context of the parable in the gospels (usually around and after 70 C.E.) accurately reflects the social context in the public career of Jesus (around 30 C.E.)... Jesus' invention of the parable in the social context of first-century life preceded the writing of the gospels.

Soos hieronder aangetoon sal word, getuig dié gelykenis van verskeie invloede van die sosio-ekonomiese wêreld van die historiese Jesus. Daar bestaan byvoorbeeld 'n opmerklike verband tussen die gelykenis en die sosio-ekonomiese konteks daarvan soos onder andere blyk uit die feit dat die jonger seun voortydig 'n deel van sy erfporsie

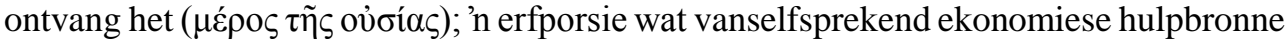
ingesluit het. Die teksgedeelte waarop gefokus word, is Lukas 15:11-13. ${ }^{3}$

In die wêreld waarin ons tans leef, gebeur dit dikwels, dat die mens vertrou op welvaart, aardse besittings of rykdom om "sinvol" te lewe. Hierdie moderne perspektief toon aan dat die jongste seun se gekose leefwyse in die ver land vanuit die staanspoor nie volhoubaar was nie. Indien hy geweet het wat hy met sy geld kon doen ten einde volhoubaarheid te verseker, en dit gedoen het, sou sy geld nie opgeraak en hy nie in die varkhok beland het nie. Laasgenoemde gedagte sluit aan by wat die kernbeginsel van die

Die verwysing na Jesus in hierdie verband dui nie na op die Jesus van byvoorbeeld Lukas of Markus nie, maar op die Jesus "voor" Lukas of Matteus. Levine (2014:16) motiveer hierdie onderskeid soos volg: "The evangelists are our first known interpreters of the parables. By adapting the language and providing a setting they have already foreclosed some meanings; by providing explications they foreclose others." Anders gestel: die fokus hier is nie op hóé die evangeliste die gelykenisse van Jesus aangewend het nie, maar op wát Jesus waarskynlik daarmee bedoel het toe Hy 'n bepaalde gelykenis vertel het.

Alhoewel daar in hierdie artikel gefokus word op Lukas 15:11-13, is dit soms nodig om na die hele gelykenis van die Verlore Seun in Lukas 15:11-32 te verwys om temas en konsepte te verduidelik. Die gelykenis as geheel sal daarom soms deel van die bespreking hieronder wees. 
"Verlore Seun" genoem kan word, naamlik dat dit meer waarde inhou om op Jesus se genade te vertrou en spesifiek volgens sy alternatiewe sosiale orde te lewe. Vanuit hierdie perspektief, word die beginsel van volhoubaarheid in die gelykenis geïdentifiseer. Verdere vrae wat in die artikel aangespreek word, is die volgende: Kan die temas van sosiale geregtigheid en volhoubare beplanning in die bediening van Jesus gevind word deur na die optrede en doel van die jonger broer in Lukas 15:11-32 te kyk deur die lens van 'n sosiaal-wetenskaplike benadering? Die gelykenis maak geen verwysing na wat die jonger seun in gedagte gehad het nie. Is dit moontlik dat die jonger seun na 'n ver land wou verhuis om daar 'n lewe vir homself te maak, en dit vanweë sosiaal-ekonomiese redes nie kon regkry nie? Lukas 15:14 maak die stelling dat die jonger seun alles spandeer het $(\delta \alpha \pi \alpha \nu$ die st). Is dit moontlik dat die historiese Jesus hier wysheid rakende verkwisting by sy hoorders probeer tuisbring het? In Lukas 15:11-32 kom daar geen verwysing na beplanning voor nie. Is dit moontlik dat Jesus in hierdie gelykenis 'n wysheid probeer kommunikeer het, naamlik dat 'n mens fyn moet beplan alvorens jy jou beskikbare hulpbronne bestee? Indien Jesus 'n sosiale evangelie verkondig het, watter kenmerke van sosiale geregtigheid kan in Lukas 15:11-32 gevind word?

As die jongste seun in die gelykenis nagedink het oor sy nuwe leefwyse en beplan het wat hy met sy nuwe geld wou doen, sou hy besef het dat sy nuwe leefstyl nie volhoubaar sou wees nie. Voordat die Verlore Seun dit sou kon agterkom, moes hy eers beplan het deur gebruik te maak van 'n begroting. Eers dan sou hy kon raaksien wat hy kon en nie kon bekostig nie. Indien hy die nodige begroting as beplanning toegepas het, sou hy besef het dat die verkwisting van geld (soos die gelykenis vermeld) nie 'n volhoubare leefwyse verseker nie, en dat hy moontlik in 'n varkhok (as werker) sou kon eindig.

Dit is duidelik dat die temas volhoubaarheid en verkwisting heel waarskynlik 'n rol in die gelykenis speel. In hierdie verband is die volgende vrae dus ook belangrik: Is dit moontlik dat die historiese Jesus in die gelykenis wysheid rakende beplanning kommunikeer? Wat probeer die gelykenis aan sy gehoor kommunikeer in terme van volhoubaarheid? Dit is in die gelykenis duidelik dat die verkwisting in verband gebring word met geld. Watter tipe wysheid kan die hoorder uit die gelykenis leer in terme van finansiële beplanning en volhoubaarheid? Wat kan organisasies (beide winsgewend en nie-winsgewend) uit die gelykenis leer in terme van Bybelse finansiële beplanning? Ten slotte: Genade blyk'n belangrike tema in die gelykenis te wees. Wat is die verband tussen genade en volhoubare beplanning?

Die sosiale konteks van die gelykenis word in hierdie artikel deeglik verreken. Daarom word die sosiaal-wetenskaplike benadering gebruik om die teks te bestudeer. ${ }^{4}$ Die sosio-kulturele, politieke, godsdienstige en ekonomiese realiteite van die NuweTestamentiese periode in Palestina word volgens Malina (2001) se vier-basis-model bestudeer. Die beskouinge van Van Eck (2015), Zimmermann (2009) en Horsley (2006) sal as hoofbronne vir die interpretasie van die gelykenis gebruik word.

Die artikel poog om die antieke hoorder se interpretasie van die gelykenis na te speur. Dit is daarom nodig dat die sosiale konteks van Palestina in die eerste eeu, as deel van

4 Die histories-kritiese metode of historiese kritiek word nie volledig in hierdie studie gebruik word nie, maar elemente van teks-, bron-, vorm- en redaksiekritiek, soos deur Law (2012) uiteengesit, word gebruik. 
die Romeinse Ryk, verstaan word. In hierdie verband word daar spesifiek aandag gegee aan die eerste-eeuse Mediterreense samelewing as 'n verweefde samelewing, die vloei van geld in die tyd van die Nuwe Testament, die vloei van belasting in die antieke tyd, grondeienaarskap in die tyd van Jesus, Jesus se interpretasie van sy sosiale konteks, en daarteenoor die vloei van geld in die moderne tyd (21ste eeu).

\section{Benadering tot die Gelykenisse}

Volgens Zimmermann (2009:158; kyk ook Zimmermann 2007:25) kan 'n gelykenis soos volg gedefinieer word:

A parable is a short narrative ... fictional ... text that is related in the narrated world to known reality ... but, by way of implicit or explicit transfer signals, makes it understood that the meaning of the narration must be differentiated from the literal words of the text.... In its appeal structure ... it challenges the reader to carry out a metaphoric transfer of meaning that is steered by co-text and context information.

Die implikasie van bogenoemde karaktereienskappe is dat 'n gelykenis 'n fiktiewe narratief is wat moontlik na 'n verwante realiteit verwys. Daar moet dus gepoog word om die realistiese elemente in 'n gelykenis te identifiseer en te verstaan alvorens die gelykenis geïnterpreteer kan word. Die realistiese elemente met betrekking tot die gelykenis van die Verlore Seun word in die sosiohistoriese konteks van Palestina in die eerste eeu gevind.

Die gelykenisse van Jesus is atipiese vertellings waarin die sosiale konteks van daardie tyd (Grieks-Romeinse wêreld) vervang word met dié van 'n ander wêreldbeeld. Die ander wêreldbeeld is die koninkryk van God; Jesus se alternatiewe sosiale orde. Die antieke hoorder het 'n verband getref tussen sy/haar Grieks-Romeinse wêreldbeeld (realisties) en die wêreldbeeld van Jesus (koninkryk van God en Jesus se alternatiewe sosiale orde). Die gelykenis van die Verlore Seun kan dus op een van twee wyses verstaan word (Van Eck 2015): dit onderskryf of bevraagteken die status quo. Hieronder sal aangetoon word dat die gelykenis die status quo van die eerste-eeuse Palestina bevraagteken het. Jesus het in die proses 'n alternatief daargestel.

Daar bestaan beduidend realistiese ooreenkomste tussen die boodskap van die gelykenisse van Jesus en die konteks van die hoorders in Palestina (in die GrieksRomeinse wêreld in die tyd van die Nuwe Testament) soos die volgende (Horsley 2006:1214, Oakman 2008:4, Snodgrass 2008:369): die gelykenisse sluit, naamlik die werkersklas in; en die werker (landbouer) is besig om vanweë sosio-ekonomiese en politieke redes beheer oor sy grond te verloor. Beide die werkersklas en beheer oor grond is deel van die wêreld van die gelykenis van die Verlore Seun.

\section{Die Sosiaal-Wetenskaplike Metode}

Van Eck (2015:5) wys daarop dat interpreteerders eers die sosiale realia of kulturele agtergrond (bv. gewoontes en gebruike) van die antieke konteks moet verken ten einde te probeer vasstel wat die bepaalde geykenis moontlik in daardie konteks wou kommunikeer. Eers dan kan gevra word wat die gelykenis moontlik binne vandag se konteks wil kommunikeer. Die antieke konteks in hierdie studie is die sosio-kulturele omgewing van Jesus. 
Hierdie artikel gebruik die sosiaal-wetenskaplike benadering om die NuweTestamentiese teks te analiseer. In hierdie benadering word sosiale modelle gebruik om 'n meer omvattende en geïntegreerde benadering te bewerkstellig, om die sosiale wêreld van Jesus te verstaan en sodoende die gelykenisse se destydse boodskap kultuur-sensitief te interpreteer.

'n Duidelike en bruikbare begrip van sosiale sisteme help om bevooroordeelde interpretasies te voorkom (Oakman 2008:246). Duidelikheid word verkry deur toe te laat dat konsepsionele raamwerke gebruik word wanneer die teks krities bestudeer word. Sulke konsepsionele raamwerke verg geskiedkundige data as bewyse van hoe die mense van daardie tyd die lewe verstaan het.

\section{Die Antieke Ekonomie en die Verweefde Samelewing}

Die ekonomie van die antieke tyd het nie losstaande van ander sosiale instellings gefunksioneer nie. Die antieke samelewing was 'n verweefde samelewing waarin die ekonomie, politiek, familie en godsdiens hand aan hand gefunksioneer het.

Die woord ekonomie het sy oorsprong in Grieks en is 'n samestelling wat die begrippe "huis" en "bestuurder" saamvoeg. "Huis" of "huishouding" kan verwys na 'n huisgesin, groot landgebied, 'n groot huishouding met baie eiendomme, of selfs 'n imperiale heerskappy (Liddell \& Scott 1897). Die "huis" van'n grondeienaar kon die "bestuur" van die plaaswerkers en hul landboubedrywighede insluit. Die Romeinse Ryk het op so 'n manier gefunksioneer dat die imperiale heersers (elite) grond as 'n groot huishouding bestuur het (Oakman 2008).

Volgens (Khumalo 2012:600) kombineer die Oxford woordeboek (Allen 1991) se definisie die basiskonsepte van ekonomie, te wete hulpbronne van 'n samelewing en hoe dit geproduseer en verbruik word. Mohr en Fourie (2008:5) verwoord die basisbegrippe van ekonomie as skaarsheid en keuse. Die twee hoofbegrippe van ekonomie, skaarsheid en keuse, kom in die besprekings in hierdie studie gereeld na vore.

Palestina is aan die Middellandse See geleë, wat handeldryf met skepe vergemaklik het. Die heersers het die meeste van die landgoed besit, en hulle of hul agente het hierdie handelsroetes oor die Middellandse See beheer en was in beheer van internasionale handel. Die antieke ekonomie in Palestina was dus in wese verweef met die politiek. Dit word 'n "politieke ekonomie" genoem (Oakman 2008). In hierdie artikel word Malina (1986:69) se model van die vier antieke sosiale sisteme gebruik om die antieke ekonomie te verstaan.

Die gereg of kerkreg

(Organisering)

Mag

\section{Verwantskappe \\ (Behoort aan) Toegewyd}

Sleutel:

Sosiale instelling

(Sosiale sub-sisteem)

Bemiddeling

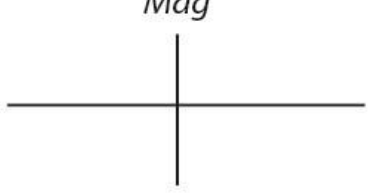

Godsdiens

(Betekenis)

Invloedryk
Ekonomie

(Aansporing)

Welvaart 
Die Grieks-Romeinse wêreld het bestaan uit ' $n$ groot groep nie-elite en 'n klein groep elite. Die nie-elite het die oorgrote meerderheid van die bevolking verteenwoordig. Hulle was die landboere en het hoë belasting betaal. Die elite het as die heersers opgetree, naamlik die koning, tempelpersoneel en die Romeinse regering.

Die nie-elite bevolking was onder groot druk vanweë belasting. Onbetaalde belasting is as skuld geag. Belasting moes betaal word aan die Romeinse Ryk, aan die plaaslike heersers (bv. Herodes Antipas), en aan die plaaslike elite (bv. die Herodiane; kyk Mark 3:6). Verder moes die meeste landboere huur betaal, al het die grond waarop hulle geboer het, aan hulle behoort. Soms het hulle lenings aangegaan ten einde hul belastingverpligtinge te dek, wat dikwels tot die verlies van hul grond gelei het omdat die lenings plus die rente daarop nie betaal kon word nie. Naas hierdie belastings, huur, en moontlike rente, was tempelbelasting 'n verdere verpligting. Daaruit blyk dit dat die heersers die nie-elite ekonomies onderdruk het.

Die tipiese wyse waarop geld in moderne ekonomieë vloei, kan nie as model dien vir die vloei van geld in Palestina in die Nuwe-Testamentiese tyd nie. 'n Ander model word benodig om die vloei van fondse in die destydse verweefde sosiale wêreld van die eersteeeuse Palestina te analiseer.

Die produkte van die landbousektor, veral die sogenaamde "surplus van die oes," is deur die staat opgeëis om in die behoeftes van die elite in die stede te voorsien. Gevolglik kon die plaasboere, wat bestaansboerderye bedryf het, minder van hul produkte vir eie gebruik oorhou. In baie gevalle is produkte ook deur die elite opgeëis om na Rome gestuur te word.

Die vloei van fondse in die antieke "finansiële belastingstelsel" het soos volg verloop (kyk Vakman 2008:74; aangepas):

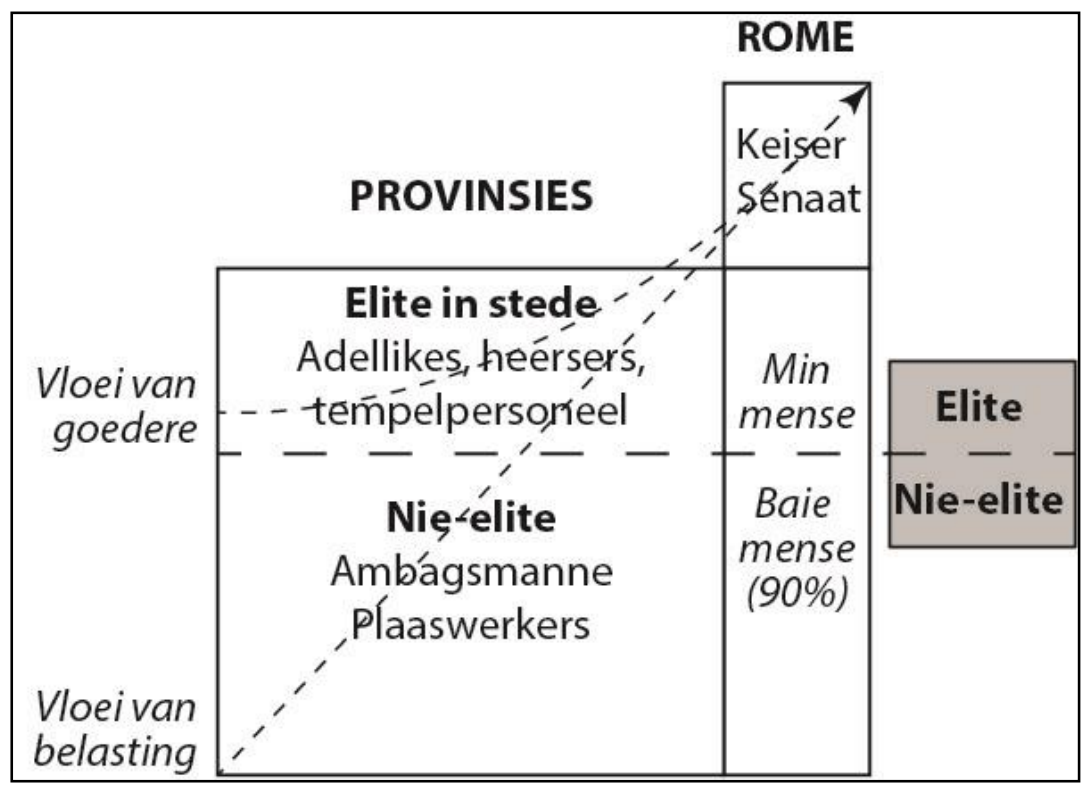


Hierdie figuur toon aan hoe die fondse en goedere in die Romeinse Ryk gevloei het. Die stippellyn pyltjies dui aan hoe welvaart, in terme van goedere en belasting, na Rome gevloei het. Die heersers het hulself dus bevoordeel deur van die samelewing te neem. Die weermag wat die samelewing namens die heersers onderdruk het, is deels uit hierdie welvaart betaal.

Die nie-elite (onder die stippellyn wat die skets horisontaal in twee helftes verdeel) was die plaaswerkers of landboere. Dit was grootliks hul belastinggelde wat die elite in die stede onderhou het en wat die elite in die stede gebruik het om hul eie belasting (aan Rome) te betaal. In hierdie model word die elite dus ryker, en die nie-elite net armer.

\section{Die Antieke Ekonomiese Invloed op die Gelykenis van die Verlore Seun}

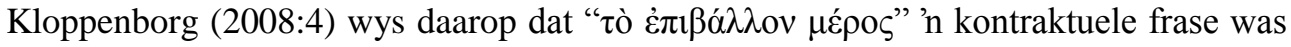
waardeur die jonger seun regmatig sy deel van die erfporsie kon aanvra. Dit sou moontlik 'n derde van die waarde van die totale erfporsie beloop. Die aanvra van die erfporsie was nie destyds negatief van aard nie (Kloppenborg 2008:21, Oesterley 1936:184, Smith 1937:194). Toe die jonger seun daarop aanspraak gemaak het sou van hom verwag word

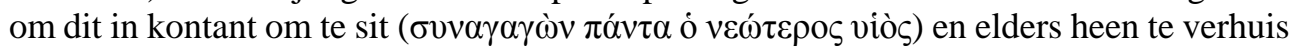
(Linnemann 1966:150). Carter (1985:104) argumenteer dat die gebeure van Lukas 15:12 'n nodige stap was, eerder as 'n negatiewe een.

Volgens die gelykenis het die seun sy erfgeld verkwis. Die verkwisting kan verskeie aksies insluit waaronder die betaal van belasting, die vermorsing van geld op plesier, of die koop van grond moontlikhede was. Die vraag is egter of dit vir die Verlorene hoegenaamd moontlik was om 'n wins te toon, en in die proses finansiële sukses in die ver land te behaal?

Die uitgangspunt hier is dat vanweë ekonomiese omstandighede, die Verlore Seun nie in die ver land 'n finansiële sukses sou kon maak nie, selfs al sou hy 'n daadwerklike poging daartoe aanwend het. Hy het daarom nie eens probeer om finansieel suksesvol te wees nie, maar het die geld verkwis.

Varvatsoulias (2010:70) interpreteer die gelykenis van die Verlore Seun op gedekontekstualiseerde wyse en argumenteer dat die rede vir die jonger broer se keuse om die huis te verlaat, onbekend is.

\section{Jesus se Alternatiewe Sosiale Orde}

Hierdie artikel fokus op die gelykenis van Jesus soos dit opgeteken is in die Lukasevangelie. Lukas teken Jesus as 'n messiaanse Koning wat die evangelie na die armes bring: "Die Gees van die Here is op My omdat Hy My gesalf het om die evangelie aan armes te verkondig. Hy het My gestuur om vrylating vir gevangenes uit te roep en herstel van gesig vir blindes, om onderdruktes in vryheid uit te stuur" (Luk. 4:18). Dit is moeilik om te bepaal of Jesus Homself as 'n Messiaanse koning gesien het. Wat egter wel aanvaar kan word, is dat die Lukaanse Jesus se fokus op die armes heel waarskynlik deel van die program van die historiese Jesus was. Jesus se fokus was duidelik op die armes, en in sy verkondiging en dade het Hy sy hoorders aangespoor om eerder op God te vertrou as op aardse goed. Die konsep van algemene wederkerigheid, om te gee sonder om terug te verwag, wat so karakteriserend van Jesus se verkondiging was, kom sterk in die Lukasevangelie na vore. 
Jesus se alternatiewe wêreld staan bekend as die koninkryk van God. Dit het lynreg teenoor die Grieks-Romeinse wêreldsisteem gestaan, wat veroorsaak het dat mense hul grond en besittings deur uitbuiting verloor het. Dit het heel waarskynlik ook met die Verlorene se erfgeld gebeur. Die Grieks-Romeinse wêreld word in die onderstaande figuur aangedui deur die linkerkantse soliede blokke; die Grieks-Romeinse wêreld wat die nie-elite deur uitbuitende praktyke benadeel het. Die welvaart van die nie-elite het opwaarts gevloei na die elite. Dit is juis hierdie sisteem wat die historiese Jesus teengestaan het en sou vervang met die koninkryk van God.

Jesus se alternatiewe sosiale orde word aan die regterkant van die onderstaande figuur aangedui. Die produk-sirkulasie verwys na welvaart en vind plaas tussen die familie (biologies, fiktief, plaasgemeenskap of geloofsfamilie), die plaaslike geloof en die plaaslike ekonomie.

Die Verlorene maak op sy familie staat ná die gebeurtenis in Lukas 15:17 en ontvang sodoende genoeg om te oorleef. Dit is opvallend dat die vaderfiguur in die model iets verstaan van algemene wederkerigheid, aangesien hy die familiekonteks so aanwend dat die Verlorene terug verwelkom word.
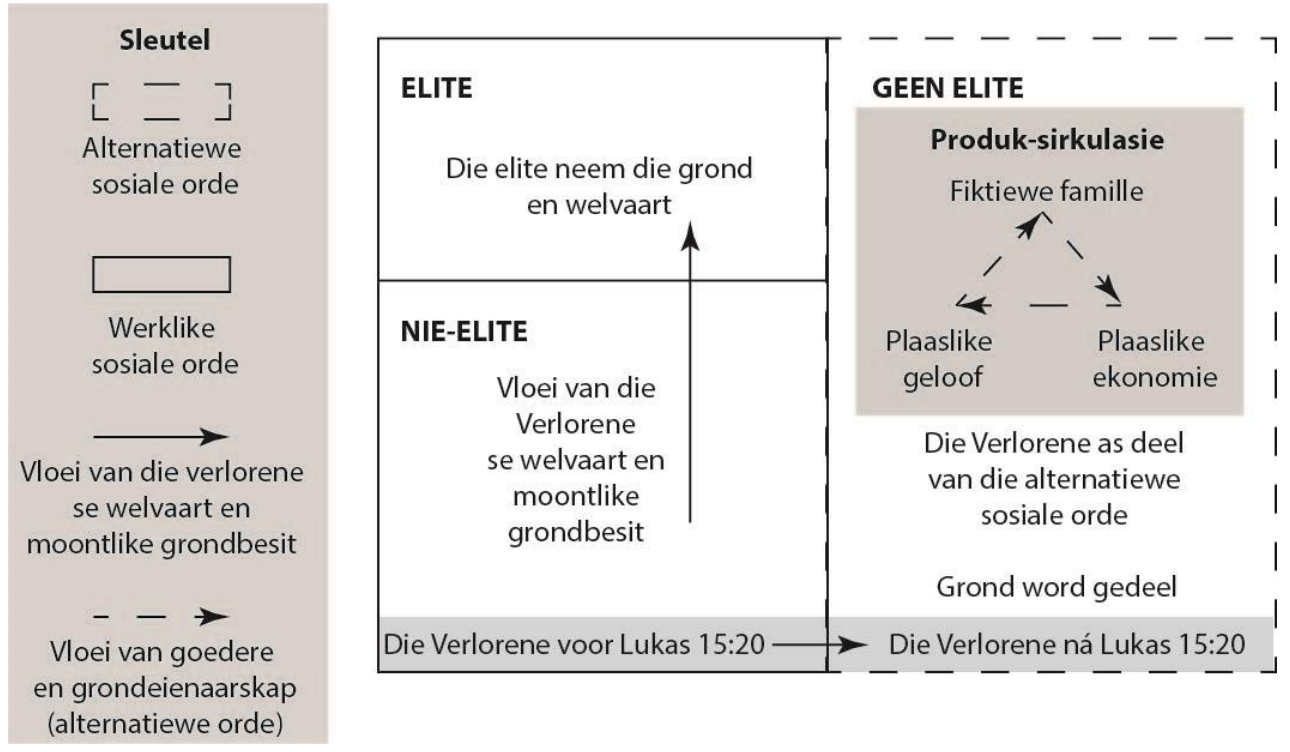

(Oakman 2008:143, 251; aangepas)

\section{Jesus se Alternatiewe Sosiale Orde toegepas op die Gelykenis van die Verlore Seun}

In die onderstande tabel word Malina (1986:69) se vier-basis-model in kombinasie met Oakman (2008:251) se model toegepas om Jesus se alternatiewe sosiale orde te identifiseer in die gelykenis van die Verlore Seun. 


\begin{tabular}{ll}
$\begin{array}{l}\text { Die Verlorene in die Grieks- } \\
\text { Romeinse wêreld }\end{array}$ & $\begin{array}{l}\text { Die Verlorene in die } \\
\text { alternatiewe sosiale orde }\end{array}$ \\
Vanaf Lukas 15:14 waar die & van Jesus \\
$\begin{array}{l}\text { Verlorene gebrek begin ly in } \\
\text { die ver land. }\end{array}$ & $\begin{array}{l}\text { Ná Lukas 15:20 waar die } \\
\text { Verlorene weer aan huis is by } \\
\text { die vaderfiguur. }\end{array}$ \\
\hline
\end{tabular}

\begin{tabular}{|c|c|c|}
\hline Verwantskappe & $\begin{array}{l}\text { Geen familie om hom te } \\
\text { ondersteun nie. }\end{array}$ & $\begin{array}{l}\text { Bevind homself in 'n } \\
\text { samelewing waar hy op ander } \\
\text { kan staatmaak (die familie). }\end{array}$ \\
\hline Ekonomie & $\begin{array}{l}\text { Sy ekonomiese welvaart (die } \\
\text { erfgeld) was nie in staat om } \\
\text { hom te onderhou nie. }\end{array}$ & $\begin{array}{l}\text { Die ekonomiese welvaart } \\
\text { word in die familieverband } \\
\text { gedeel. }\end{array}$ \\
\hline Politiek & $\begin{array}{l}\text { Geen politieke verwantskappe } \\
\text { nie. }\end{array}$ & $\begin{array}{l}\text { Die familieverband neem die } \\
\text { politieke werktuig oor. Hy } \\
\text { het in dié opsig 'n politieke } \\
\text { posisie. }\end{array}$ \\
\hline Godsdiens & $\begin{array}{l}\text { Hy is in omstandighede waar } \\
\text { hy nie sy godsdienstige wette } \\
\text { kan uitleef nie. }\end{array}$ & $\begin{array}{l}\text { Hy kan sy godsdienstige } \\
\text { wette in die familieverband } \\
\text { nakom. }\end{array}$ \\
\hline
\end{tabular}

(Malina 1986:69, Oakman 2008:251; toegepas op die gelykenis)

Die bostaande tabel dui duidelik die waarde van Jesus se alternatiewe sosiale orde in die konteks van die gelykenis van die Verlore Seun in Lukas 15:11-32 aan. Die artikel toon dus verskeie beginsels aan wat geïdentifiseer en ontwikkel kan word vir die moderne individu en die owerheid in die wêreld van die 21 ste eeu.

\section{Beginsels vir Vandag}

In hierdie afdeling word die voorafgaande toepassing van die sosiaal-wetenskaplike metode prakties gebruik om beginsels vir vandag te ontgin. Die beginsels skakel direk met die gelykenis van die Verlore Seun in Lukas 15:11-13.

\section{Jesus se Sosiale Motief}

Jesus het sosiale en politieke motiewe gehad (soos aangetoon). Dit sluit in dat die historiese Jesus die armes wou help deur 'n beter wêreld vir hulle te skep. Die rede hiervoor was dat die Grieks-Romeinse wêreld 'n uitbuitende ekonomie gehad het waaraan die verweefde samelewing uitgelewer was.

Daar is alreeds aangetoon dat Jesus se bediening op aarde in 'n onstuimige tyd in Galilea en Palestina afgespeel het. Die Romeinse weermag het ongeveer 10 jaar voor die geboorte van Jesus 'n bloedige veldtog in Galilea gevoer teen mense wat potensieel van belastingontduiking verdink is. Jesus het in 'n tyd geleef waarin 'n militêre veldtog of enige protesaksie teen die Romeinse Ryk sou misluk.

Jesus het gereeld sondaars en tollenaars (mense wat belasting ingevorder het) onthaal. 'n Moontlike gevolgtrekking is dat Jesus die skuld van die armes probeer verminder het. Hy het vir die skuldeisers en tollenaars probeer aantoon dat dit beter vir die samelewing sou wees indien hulle eerder die armes se skuld sou afskryf. 
Die Romeinse Ryk was egter op 'n politieke netwerk gebaseer. Dit kan ook 'n kliëntebasis genoem word (soos reeds aangetoon). Plaasboere was kliënte van die dorpsbewoners, die dorpsbewoners van die stadsbewoners, die stadsbewoners van die provinsiale regering en die provinsiale regering van die keiser in Rome. Dit sou die politieke netwerk versteur indien een persoon in die netwerk minder aan die ander betaal het.

Dit was dus 'n komponent van Jesus se bediening om die Grieks-Romeinse wêreld met ' $n$ alternatiewe sosiale orde te vervang. Jesus se alternatiewe sosiale orde staan ook bekend as die koninkryk van God. In hierdie studie is die sosiaal-wetenskaplike metode gebruik om die begrip van algemene wederkerigheid in die koninkryk aan die hand van die gelykenis van die Verlore Seun aan te toon.

\section{Grieks-Romeinse Wêreld vergelyk met die Wêreld van die 21ste Eeu}

Die antieke belastingstelsel teenoor die moderne belastingstelsel in Suid-Afrika

Die moontlike uitbuitende praktyke van die wêreld van die 21 ste eeu lyk aansienlik anders as dié van die Grieks-Romeinse wêreld. In die Grieks-Romeinse wêreld het die armes hoë belasting betaal (Oakman 2008:251). In die moderne tyd probeer die owerheid van Suid-Afrika verseker dat die armes minder belasting betaal as die welvarendes (Mohr \& Fourie 2008:79, South African Reserve Bank 2018). Die Grieks-Romeinse wêreld en die wêreld van die 21ste eeu (in Suid-Afrika) kan dus in terme van armes en randfigure nie met mekaar vergelyk word nie. In die Grieks-Romeinse wêreld het die belasting gevloei vanaf die armes (nie-elite) na die rykes (elite). Die Suid-Afrikaanse owerheid probeer die situasie omkeer, naamlik dat die armes deur die belastingstelsel bevoordeel word. Dit is egter nie die doel van hierdie studie om die huidige sisteem in Suid-Afrika te beoordeel nie.

Soos alreeds aangetoon, was dit in die Grieks-Romeinse wêreld die plaasboere en die nie-elite wat die elite in die dorpe en stede onderhou het. Indien daar in die Romeinse Ryk 'n beweging was wat 'n stem vir die armes was, is dit, soos Judas van Gamala, stilgemaak. Dit wil uit die geskiedenis (Whiston 2018) asook uit die Bybel voorkom asof die armes nie 'n stem gehad het in Palestina in die tyd van die Nuwe Testament nie.

Volgens Mohr en Fourie (2008:85) word Suid-Afrika gekenmerk deur 'n skewe verdeling van inkomste tussen huishoudings en individue. Die ekonomiese maatstaf van ongelykheid tussen die individue van 'n land word deur die Gini-koëffisiënt uitgedruk. Dit word algemeen aanvaar dat Suid-Afrika een van die wêreld se hoogste Ginikoëffisiënte het. Suid-Afrika het dus een van die mees ongelyke verdelings van inkomste ter wêreld (Mohr \& Fourie 2008:75).

Mohr en Fourie (2008:86) toon aan dat die Suid-Afrikaanse owerheid funksionele verdeling van inkomste toepas om die groot ongelykheid in terme van dié verdeling in die land te verklein. Die proses van funksionele verdeling van inkomste was sedert 1994 beduidend suksesvol.

Mohr en Fourie (2008:454) toon aan dat owerhede slegs geld kan spandeer indien hulle belasting verhaal. Die staat bestee geld om armes op te hef. Dit sluit die SuidAfrikaanse owerheid in. Belasting is dus die bron van die staat se sosiale werk. Hoë belasting ontmoedig egter investering, wat op sy beurt ekonomiese ontwikkeling vertraag. 
Skuld en arm lande

Mohr en Fourie (2008:547) toon aan dat minder ontwikkelde lande (MOL'e) verskeie probleme ervaar wat ekonomiese groei en ontwikkeling teenwerk. Die gebrek aan kapitaal is sodanige probleem. Indien die oorgrote meerderheid van 'n land se bevolking hulself in die lae inkomstegroep bevind, is daar min bronne van kapitaal in die land. 'n Moontlike bron van kapitaal is dan buitelandse investering.

Buitelandse beleggings word nadelig beïnvloed wanneer dié land se belastingkoers hoog is. Die rede hiervoor is dat welvarende internasionale organisasies nie geneë is om kapitaal te belê in lande waar die hoë inkomstegroep hoë belasting betaal nie. Belasting dra 'n land se skuld. Indien 'n land baie skuld het, word hoë belasting gehef om die skuld te delg. Hoë belastingheffings ontmoedig investering in die bepaalde land, wat ekonomiese groei en ontwikkeling nadelig beïnvloed. Minder ontwikkelde lande se skuld behoort afgeskryf te word, sodat investering vir internasionale beleggers aanloklik kan wees.

Indien die skuldeisers van minder ontwikkelde lande die konsep van algemene wederkerigheid toepas, kan hulle die lande se behoeftiges help. Jesus se alternatiewe sosiale orde sou dus moontlik op 'n globale skaal toegepas kon word.

\section{Beplanning}

Seal, Garrison en Noreen (2009:434) definieer die konsep, “begroting” as 'n geëtaleerde plan vir die aanwending en gebruik van finansiële en ander hulpbronne oor'n spesifieke tydperk. Dit verteenwoordig 'n plan vir die toekoms, uitgedruk in formele hoeveelhede. Twee aspekte van die begrotingsproses is naamlik:

- Beplanning - dit sluit die ontwikkeling van doelwitte en voorbereiding van begrotings om spesifieke doelwitte te bereik, in.

- Beheer - dit sluit in die stappe wat rolspelers neem om die kans om die doelwitte te behaal, te vergroot.

Die gelykenis van die Verlore Seun in Lukas 15:11-13 toon geen beplanning nie. Die Verlorene het slegs sy erfporsie in geld omgesit en daarvan gaan leef. Die feit dat hy nie beplan het nie, sou hom uiteindelik tot 'n val bring. Die feit dat hy sy geld verkwis het, is slegs 'n bykomende faktor.

Die gelykenis van die Verlore Seun toon aan dat finansiële beplanning met behulp van 'n begroting noodsaaklik is. Seal et al. (2009) wys daarop dat die meeste mense onwetend deelneem aan 'n proses waardeur daar begroot word. 'n Individu of huishouding kan byvoorbeeld min of meer skat wat die inkomste en uitgawes in 'n maand (spesifieke tyd) sal wees. 'n Individu of huishouding maak dan keuses op grond van daardie geskatte beplanning.

In die gelykenis van die Verlore Seun het die Verlorene nie beplan met 'n begroting nie. Die vaderfiguur het wel genoeg gehad om van te leef (Lukas 15:17). Dit is dus moontlik dat die familie en die vaderfiguur'n begroting gehad het. 


\section{BIBLIOGRAFIE}

Allen, R 1991. The concise Oxford dictionary of current English, 8th ed. Oxford: Clarendon Press.

Horsley, RA 2006. "Early Christian movements: Jesus movements and the renewal of Israel", HTS Teologiese Studies/Theological Studies, 62(4), 1201-1225.

Khumalo, B 2012. "'Defining economics in the twenty first century", Modern Economy, 3(1), 597-607.

Kloppenborg, JS 2008. "The Parable of the Prodigal Son and Deeds of Gift", Jesus, Paul, and Early Christianity: Studies in Honour of Henk Jan de Jonge' 169-194.

Law, DR 2012. The Historical-Critical Method: A Guide for the Perplexed. New York:, T\&T Clark.

Liddell, HG and Scott, R 1897. A Greek-English lexicon, New York: American Book Company.

Linnemann, E 1966, Parables of Jesus: Introduction and Exposition, S.P.C.K., Indiana University.

Malina, BJ 1986. “'Religion' in the World of Paul”, Biblical Theology Bulletin: Journal of Bible and Culture. 16(3), 92.

Malina, BJ 2001. The social gospel of Jesus: The kingdom of God in Mediterranean perspective Minneapolis: Fortress Press,

Mohr, P and Fourie, L 2008. Ekonomie vir Suid-Afrikaanse studente. Pretoria: Van Schaik Uitgewers.

Oakman, D 2008. Jesus and the peasants: (Matrix: the Bible in Mediterranean Context). Eugene: Cascade Books.

Oesterley, WOE 1936. The gospel parables in the light of their Jewish background, Society for promoting Christian knowledge.

Seal, W, Garrison, RH and Noreen, EW 2009. Management Accounting. Glasgow: McGraw-Hill Higher Education

Smith, BTD 1937. The Parables in the Synoptic Gospels. Cambridge: Cambridge Press.

Snodgrass, K 2008. Stories with intent: A comprehensive guide to the parables of Jesus, Grand Rapids MI: Wm. B. Eerdmans Publishing.

South African Reserve Bank, South African Reserve Bank, viewed 2018-06-06, from https://www.resbank.co.za/Pages/default.aspx.

Van Eck, E 2015. "Die gelykenisse van Jesus: Allegorieë of simbole van sosiale transformasie?", HTS: Theological Studies. 71(3), 1-10.

Whiston, W Josephus - The antiquities of the Jews, vertaal deur Whiston, W. voorberei deur Blackmask Online, BoD-Books on Demand.

Zimmermann, R 2007. "Die Gleichnisse Jesu: Eine Leseanleitung zum Kompendium." In R Zimmermann, D Dormeyer, G Kern, A Merz, C Münch \& E.E. Popkes (eds.), Kompendium der Gleichnisse Jesu. (3-45). München: Gütersloher Verlagshaus.

Zimmermann, R 2009. "How to understand the parables of Jesus: a paradigm shift in parable exegesis.” Acta Theologica. 29(1), 157-182. 